\title{
Intermodality in Italy during the Fascist Period: A Case Study
}

\author{
Stefano Maggi \\ Department of Political Science, University of Siena, Siena I-53100, Italy
}

\begin{abstract}
In the 1930s, when the competition among trucks and trains started, the Fascist government in Italy tried to implement a first form of road-rail integration. As a result, in this period, a transport intermodal network existed for transport services for both freights and passengers. However, the network was quickly lost after the Second World War. The research objective of this paper regards the method of construction of a first form of intermodality (even before this term was used), through the analysis of theoretical texts and achievements of the era. The paper examines laws and regulations issued by the Fascist government. It shows how the willingness to implement a transport policy would lead to having coordinated transport. The success was not only political but also economic, as the coordinated transport may be cheaper and more effective.
\end{abstract}

Key words: Passenger and freight intermodality, trains and trucks, the 1930s, Fascist period.

\section{Introduction}

"The railway in comparison to the other means of transport introduces conditions that have allowed to establish a principle of great importance: that of the obligation of the transport. This principle affirmed only in comparison of the railway has an inestimable social value. The commerce and the industry can count on the railway transport, make sure that it will never miss and they can make assignment on the stability of the price that cannot be varied without prescribed formality to ensure the interests of the customers. The obligation of the transport is the correspondent one of the recognition of the monopoly from the State ${ }^{1}$. The railway mechanism has had a discipline that has made it become essential element of the national structure, anything of connected to the modern life, of necessary to the social demands. There is no economic difficulty for which you do not ask for help to rail. Human solidarity in the railway has the

Corresponding author: Stefano Maggi, Ph.D., professor, research fields: transport history and railway management. E-mail: stefano.maggi@unisi.it.

${ }^{1}$ In Italy, the railway were nationalized in 1905 , creating the State Railway (Ferrovie dello Stato). best benefit""

Since ancient times, for the purpose of trade, there were means organized as intermodal transport. It has always been the transfer of goods from cars to ships, from the camels to the barges, from a wagon to another, from a ship to a boat. Nevertheless, the intermodality has brought a great development in the last two centuries, for the arrival of the train and the motor transport. Trains and trucks have increased the traffic of commodities within the States. They have created competition, before between railways and rivers or channels, then between trains and trucks.

This essay is dedicated to the first attempts to coordinate the various means of transport and to carry containers transferable from one means of transport to another. The study refers to the first half of the 20th century, particularly the 1930s, when the debate on intermodality had not yet

${ }^{2} \mathrm{~F}$. Tajani, Competition and monopoly in transport, The fight between rail and car (Concorrenza e monopolio nell'esercizio dei trasporti. La lotta tra ferrovia ed automobile), Milan, 1936, p. 46. 
developed ${ }^{3}$.

In the 19th century, the State started to practice more functions in the sector of the transports, assigning to private societies the construction and the management infrastructures, or constituting public firms as the State Railways founded in 1905 or their correspondent at a local level, the firms of transport of the Communes, provided from a law of $1903^{4}$.

At the beginning of the 20th century, it was thought the creation of networks of multiple carriers in an overview. For example, in 1907, it was imposed by law the so-called "cumulative service" among vectors of transport, to favor the development of traffic. The enterprises of transport were invited to join among them and to conclude a single contract of carriage, to favor the consumers, that paid only once for a consignment on more vectors with the same or with different ways of transport ${ }^{5}$.

In the 20th century, it has become increasingly clear the need for a transport policy which can coordinate transport and not only to promote the traditional development of mobility. The development of mobility had always been the purpose of the transport policies: for instance, the Roman roads or the intervention of States in the naval sector.

To coordinate the ways of transport means to stimulate the use of the most proper mean for the demands, since any mean could guarantee the best technical-economic conditions for all transports. This

\footnotetext{
${ }^{3}$ Le transport combiné: 50 ans d'expérience, sous la direction de Michel Rachline, Compagnie nouvelle de conteneurs-transports nationaux et internationaux, Ed. Atlas, 1997; COST 340, towards a European intermodal transport network: lessons from history: a critical bibliography, edited by Michèle Merger and Marie-Noëlle Polino, Paris, AHICF, 2004. ${ }^{4}$ Law 29 marzo 1903 n. 103, "Direct taking of public services by local authorities", according to which the municipalities could take the direct exercise, among other services, tramways animal traction or mechanical.

${ }^{5}$ Law 7 luglio 1907 n. 429, "Structure of the exercise of State Railways not granted to private companies". Article 42 recited: "It is mandatory for rail connected to each other, the establishment of cumulative service.... The obligation of cumulative service or mail, as appropriate, will be enrolled in any granting new or renewed for land transport companies, and shipping companies subsidized by the state or local authorities".
}

need was very felt in the years 1920s and 1930s, due to the diversification of means of transport and competition between them. In this period, a debate developed on rates suitable to foster trade, and interventions were needed to restrain competition among trucks and trains.

But it was a new situation and nobody knew what steps to take.

In the $1930 \mathrm{~s}$, a lot of studies on the competition between road and railway were produced ${ }^{6}$. In Italy, the Fascist government put into effect measures for rationalization of motor transport, adopting innovative solutions, subsequently abandoned after the Second World War.

\section{Debates and Proposals in the 1930s}

Until the roads were frequented only by animal-drawn vehicles, the railway offered a faster service and more convenient prices. The animal traction was a completion of the railway transport. The consignments were transported with wheelbarrows to horses from the store of the sender to the station of departure and then from the station of arrival to the warehouse of the consignee.

The truck changed the situation, because, thanks to motorized transport, it was possible to go "from door

\footnotetext{
${ }^{6}$ Compare, such as: P. Biraghi, Defense of the railway and tramway traffic (Difesa del traffico ferro-tranviario), Rome, 1931; Q. Capaccioli, Discussion on competition between rail and car (Discussioni sulla concorrenza fra ferrovia e automobile), Florence, 1933; F. Corini, Economic comparison between the various means of transport (Confronto economico fra i vari mezzi di trasporto), Parma, 1934; B. Bolis, Roads for trucks and railways (Strade camionabili e ferrovie), Rome, 1936; V. Mezzatesta, Transport in the economic life of the Nation and the issue of motor vehicles (I trasporti nella vita economica della Nazione e la questione automobilistica), Rome, 1935; A. Pavone, Motor vehicle and rail (Autoveicolo e ferrovia), Rome, 1935; F. Tajani, Competition and monopoly in transport. The fight between rail and car (Concorrenza e monopolio nell'esercizio dei trasporti. La lotta tra ferrovia e automobile), Milan, 1936; R. Trevisani, (The competition between road and rail transport in economic policy) La concorrenza fra la strada e la rotaia nella politica economica dei trasporti, Milan, 1937; F. Vezzani, Land transport (I trasporti terrestri), Florence, 1937; A. Pagello, On a form of coordination of transport ( $\mathrm{Su}$ una forma di coordinamento dei trasporti), Vicenza, 1939
} 
to door", making to save the expense of load and unloading of the railway wagons and the two animal-drawn transports. The truck could compete with the train even if it asked for more elevated prices for the transport of the commodity. The advantage of the truck went down with the growth of the total run. Competition of mechanical traction on the road was more effective on short distances and less effective over long distances.

Besides, the truck allowed to eliminate or to reduce the expense of packing. The trucks were escorted for the whole trip by the same person, the driver, who could assume the responsibility of the load without a minute packing of the commodity, while the railway was very demanding and bureaucratic.

The transport on trucks did not have excessive formalities and allowed to bargain the price of transport from time to time. Instead, in the railway, there were invariable prices, of difficulty calculation, accompanied by complicated and binding conditions. The railways, accustomed to a monopoly, had exaggerated the bureaucracy of their duties ${ }^{7}$.

This awareness spread to the early 1930s. To face the trucks, the railways lowered the rates in all cases in which the competition entered, maintaining the previous rates where the competition did not exist. One of the hinges of the public service, the parity of treatment, ended. Besides, the elevated prices were paid by the poorest clientele, that of the countries with little traffic, where motoring did not exist. The damage of the competition was twofold: to move a portion of the costs of transport from users to taxpayers and the destruction of equal treatment borne by the population less favored.

Among the measures to resolve this situation, it was proposed to adopt a partnership between rail and road transport, which was an agreement to divide the field of freight transport. But the accord between the railway and a big number of enterprises of trucks was not possible. Moreover, the lorries were in

\footnotetext{
${ }^{7}$ F. Tajani, Competition and monopoly in transport, pp. 28-29.
}

competition with each other, as well as being in competition with the railway ${ }^{8}$.

In Italy, there was a long discussion on the proposal to apply to freight service to the institution of concession applied to the bus in the early years of the 20th century. The concession was a government licence, which included an agreement between the State and the private company, that provided precise requirements for transport, in exchange for a monopoly over a certain route or for a certain service.

The system of government license for the bus lines had not created problems and had helped to develop the traffic in the regions devoid of railways and tramways, eliminating the problems that were encountered in other countries due to the excessive competition of bus lines, both between them, and with the railways and tramways 9 .

Among passenger services and commodity services, there was nevertheless a substantial difference. The traveller services had the obligation of the regularity of the schedule, while for the commodities this obligation did not exist.

In fact, the transport of foodstuff and pressing consignments were provided the same bus called "postal coaches". The other transports of commodities, did not have usually a character of such urgency to impose the departure of a truck to a fixed date and with fixed itineraries, but with an incomplete load. For this kind of transport, the criterion of greater economy always prevailed over that of regularity.

Besides, for the commodity services a determined itinerary could not be established, since the truck had to go to load the commodity to the station or to the store of departure, and to unload it to that of destination with varying itineraries of time in time. Therefore, in Italy, it was thought that it was not appropriate to establish the concession for freight

\footnotetext{
${ }^{8}$ F. Tajani, Competition and monopoly in transport, p. 39 .

${ }^{9}$ Law 12 luglio 1908 n. 444, "construction and concession of railways, trams and suburban bus lines and lake navigation in public service".
} 
services ${ }^{10}$.

A measure put in place consisted in the institution of intermediary corporate bodies which had the function to assume the transports for a global price which included the rail and road fee. It dealt with creating a corporate body able to be on the market together with the private firms of transport, which was not submitted to the rigors and the ties of the public administrations ${ }^{11}$.

The existence of the intermediary institute did not eliminate, however, the cause of the competition and the intermodal transport was preferred only if the total cost resulted smaller.

The establishment of an intermediary institution and the imposition of a tax, in order to balance the costs between trains and trucks, were founded attempts to cope with competition road/rail during the 1930s.

\section{Italy Looked Like Other European Countries}

The growth of the traffic commodities on the trucks found unprepared the political authorities, that left full liberty to the transports with truck in the first times, without worrying about the consequences. Then, the governments were induced to run for cover because of the gravity of the damages suffered by the railways. The situation in the mid-1930s was as follows.

In England, with a 1930 law the concession had been introduced for the public services of the travellers, but up to 1934 the trucks enjoyed of full liberty. In January 1934, it went into effect a new rule, which extended to freight services the obligation to grant, when trucks made services out of the circle of the city. There were three types of licenses: the first Type A to be issued to those who transported goods of others (the professional road hauliers), the second Type B for those carrying goods of themselves or others; and the third Type $\mathrm{C}$ for those carrying only their products.

\footnotetext{
${ }^{10} \mathrm{~F}$. Tajani, Competition and monopoly in transport, pp. 53-54.

${ }^{11}$ But what is this INT? (Ma che cosa è questo INT?), extract from Bollettino di Informazioni 5 (October-November 1956), p. 1.
}

The third type of license was granted on simple request, but sometimes merely granting the transport of specific goods and certain routes or traffic areas.

In France with a decree of April 1934, the concession was introduced for the public services both of travellers and commodities. If the railway companies were opposed intervened an arbitration entrusting a commission where the railways, drivers and users were represented. If the arbitration response were contrary, the Ministry of Public Works denied the concession. Some small railway stations were closed, but it was recognized that the maximum in long-distance transport was entitled to the railways.

In Switzerland, without adopting laws that regulated the auto transport of the commodities, the problem was solved by creating an intermediary institute that would have had to realize the collaboration. A proposal of law that had the tendency to regulate the transports of commodities with trucks, to the purpose to limit the competition to the railways, it was rejected from the popular referendum.

In Germany, the concession did not exist for the services travellers, while for the commodities it was made distinction among the traffic to small and that to great distance. In traffic, at a small distance ranged transport not more than $50 \mathrm{~km}$. For these transports, like those made by individuals on their own, permission from the authorities was not necessary.

Instead, the transports for more than $50 \mathrm{~km}$ done for other people's account were subdued to a concession, with the prohibition to adopt costs too low to avoid damage to the railway. In addition, carriers had to gather in a consortium that had to enter into a contract with Reichsbahn for the division of the areas.

In Austria, the concession of the services commodities was founded in 1933, as it already existed for the services travellers.

In the different national legislations, some common characters were found:

(1) Distinction was made between transport operations on their own and with their own means and 
transported on behalf of others. Transport on own account were always most favorite;

(2) Distinction was made between short-distance transport and long-distance transport. The first thought to be suitable to the truck, the second to the rail. Transport within short distance was left larger freedom, those long distance were allowed with some restrictions or even prohibited;

(3) There was a tendency to the monopoly for the Railways, making to intervene the railway administration in the inquiry for the concessions or in accords to divide the traffic;

(4) It was common to all the legislations that the tendency to put taxes on the auto services, to safeguard the railway traffic ${ }^{12}$.

This last provision was adopted in Italy in 1935. Since the rates of the trucks were too low in relation to the rail, a decree law of December 1935 taxed for 1.2 cents every quintal-km transported on truck for third parties and for 0.8 cents every quintal-km transported in own account, with exclusion of the connections among stations and place not served by the trains ${ }^{13}$. Transport carried out within the boundaries of the province, that were used to carry out the normal activities of a farm, were also exempt from duty. With such decree the firms of transport were also forced to hold registers of load and unloading of goods in order to be checked and to have a minimum of order in the administration.

The most important intervention was the constitution of the INT (National Institute of Transport), formed in 1929 when it was begun to warn the competition especially in the Valley Padana, that is in the richest part of the Country.

\section{The National Institute of Transport}

Following the examples of Switzerland and France, where some intermediary bodies had been founded to handle freight traffic. In 1929, the Italian State

\footnotetext{
${ }^{12}$ F. Tajani, Competition and monopoly in transport, pp. 49-50.

${ }^{13}$ Royal Decree-Law 2 December 1935 n. 2.097, "tax on transport of things with vehicles".
}

Railways (FS) were authorized to participate in enterprises in form of stock companies, having as purpose the acquisition and the increase of the transports for railway and the exercise of complementary services ${ }^{14}$.

The INT was created for this purpose. The undersigned initial capital was of 28 million liras, of which 21 million liras are from the State Railways, that did not put money. The State Railways conferred services as the shipping agencies of cities, the rights of use of the stores and the railway areas, the transmission of correspondence and telegraphic and telephone dispatches ${ }^{15}$. The remainder of the social capital, that is 7 million liras, was versed from the banks of investment: Commercial Bank, Italian Credit, National Bank of credit and Bank of Rome, that went out in 1936 for the new banking law that imposed the separation between bank and industry. To that point, the FS ransomed the 7 million and they remained the alone stock of the INT.

The action of the INT practiced especially in services in small quantities, that is, on the trafficking of various goods which did not fit the railway, which was a wholesaler rather than a retailer of transport. For the State Railways, the unit was neither the ton-km nor the wagon-km, but the train- $\mathrm{km}^{16}$.

To the INT which was assigned the acquisition of transport in small quantities, the task of the so-called "groupage" was to group them in order to make shipments to full wagon (wagon groupage). The INT was therefore devoted to this specific activity, both through its "delegations" (branch offices), both in partnership with the shipping agencies.

According to the convention July 14, 1929 with the State Railways, to the National Institute of Transport was granted the delivery of goods at home by its own

\footnotetext{
${ }^{14}$ Royal Decree 13 maggio 1929 n. 836, "participation of the State Railways in companies with a view to the acquisition and increase of rail transport and the operation of complementary services".

${ }^{15}$ Istituto nazionale trasporti, In twenty-five of the INT (Nel venticinquennale dell'INT), Rome, 1955, p. 15.

${ }^{16}$ But what is that INT?, p. 1 .
} 
trucks. The INT began such activity on January 1, 1930 and before June 30, 1930, it also assumed the exercise of 118 agencies of shipping ${ }^{17}$.

The agencies of new institution and some of those existing extended the service of transport for distant places from the stations. Communes were connected distant from the railway up to $40 \mathrm{~km}$ and it was made possible, also for small centers, a regular service that offered the safety of accessible and equal prices in any period of the year ${ }^{18}$.

The concept was to concentrate by truck, a good quantity of goods in a big station, put it on a fast railway service to another station and then to drain the whole by suitable trucks to the individual recipients. It was in fact the response of the railways who came in the truck to stand up to competition of this, using it as a means connected to the train.

At the beginning, the INT had the role to call the great societies, offering them special tariff facilitations, in order to make the railway transport more advantageous, completing it by a truck service that would allow the forwarding of the goods to the customer location.

In 1931, the INT had already repurchased to the State Railways around 200,000 t of commodity. Other $247,000 \mathrm{t}$ of goods were taken from the train and carried to the recipients, coordinating trains and trucks ${ }^{19}$.

From July 1931 to June 1932, the INT opened 46 new shipping agencies of city, extending besides the home service to around 300 new places not served by the railways. In some places, the agencies of city realized the collection and delivery of express packages and luggage at home.

\footnotetext{
${ }^{17}$ Ministero delle Comunicazioni: Amministrazione delle Ferrovie dello Stato, Report for the financial year 1929-30 (Relazione per l'anno finanziario 1929-30), Rome, 1930, p. 141.

${ }^{18}$ Ministero delle Comunicazioni: Amministrazione delle Ferrovie dello Stato, Report for the financial year 1930-31 (Relazione per l'anno finanziario 1930-31), Rome, 1931, p. 146.

${ }^{19} \mathrm{G}$. Gazzetti, The train at home, pp. 71-72.
}

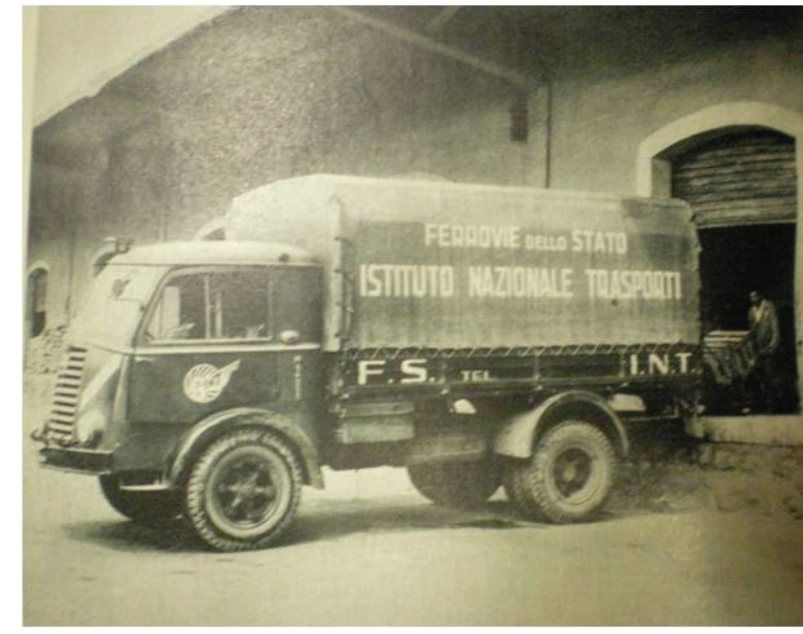

Fig. 1 Truck of the INT.

Source: G. Gazzetti, Il treno in casa, Quaderni delle Ferrovie Italiane dello Stato, n. 8, edizione 1957, p. 76.

In June 1932, the shipping agencies of city were 337, which grew to 360 in June 1934, including the direct management of the largest agency of the city of Milan. In June 1939, the agencies of city were 373 with 415 addresses in suburban locations. Besides, the INT directly managed the Agencies in Milan and Trieste, from January 1939, also in Rome.

After the Second World War, the service of the delegations INT had a further expansion reaching 449 to June 1956, of which 14 were conducted in direct management by the institute ${ }^{20}$.

Besides, to the INT, some passenger services by bus were entrusted replacing the train services ${ }^{21}$. The buses of the INT replaced the trains in two secondary lines Giulianova-Teramo and San Benedetto of the Tronto-Ascoli Piceno, since March-April 1932. The substitution happened in base to the regal decree-law December 21, 1931 No. 1575, that authorized the State Railways to replace the railway services by coach services for passengers and for commodities.

Other passenger services were subsequently assigned to the Institute: In June 1938, the coach

\footnotetext{
${ }^{20}$ Ministero dei Trasporti. Ferrovie dello Stato, Report for the financial year 1955-56 (Relazione per l'anno finanziario 1955-56), Rome, 1957, p. 224.

${ }^{21}$ Ministero delle Comunicazioni. Amministrazione delle Ferrovie dello Stato, Report for the financial year 1955-56 (Relazione per l'anno finanziario 1955-56), Rome, 1932, pp. 122-126.
} 
services managed in substitution of railways measured $388 \mathrm{~km}$ and those gotten in concession $787 \mathrm{~km}^{22}$.

To create a network of public road transport at the national level, the State could use the INT. Instead, after the Second World War, it was decided to make room for private companies and a great number of bus companies were established at the local level.

In conclusion, the complex of concessional coaches of the INT was not so important, compared to the national network of coaches, to become effective instrument of State policy to guide the development of the road transport of travelers ${ }^{23}$.

\section{The Italian Transports Company East Africa}

In East Africa, after the conquest of Ethiopia from Italy, in August 1937, a company for the coordination of all trucking services was founded, named CITAO (Italian Transport Company East Africa). The company did not have ends of profit and could acquit its own duties being free from the bureaucratic procedures of the State. The company watched over on the organization of the enterprises and on the efficiency of their vehicles. Besides, it distributed the loads among the authorized firms, holding back on the hires a share of $4 \%$. The advantage for the firms of truck was to be able to receive the price of the transport within 10 days from the offices of the company. The CITAO got a great success. Its functions had widened in 1939, when any activity inherent to the transport was entrusted to the company. The CITAO also practiced the autolinees on the main routes and also began after 1939 to manage the urban buses, that were activated in the principal cities of the colonies up to the Italian defeat in the Second World

\footnotetext{
${ }^{22}$ Ministero delle Comunicazioni. Amministrazione delle ferrovie dello Stato, Report for the financial year 1955-56, p. 106.

${ }^{23}$ Istituto nazionale trasporti, In twenty-five of the INT, pp. 18-19.
}

$\mathrm{War}^{24}$

\section{Railway Links and Containers}

With regard to the technical means by which it was attempted to facilitate intermodal transport in order to give work to both trains and trucks, we can mention the railway links, very useful for factories and department stores.

Before the motor transport assumed importance, the State Railways did not promote the construction of the links: indeed, they hindered in any way with technical pretexts and they made a very expensive exercise, applying high taxes.

When they changed policy for the arrival of the competition, the demand for railway links decreased, as a consequence of the perfecting of trucks.

Some big bogies were also created, equipped with wheels to tires, which could go from the railway tracks to city streets, carrying the railway wagon with the help of a powerful tractor, so that it reached the recipient's home address. Such means of conveyance met, however, limitations on the narrow roads of the cities. It was also a very expensive transport that could not have spread $^{25}$.

Other technical means, which emerged with the arrival of competition, was the transport container with boxes large enough to accommodate both the truck and the railway wagon.

The State Railways participated in the work of the competition organized by the International Chamber of Commerce, along with other bodies, on the initiative taken by the World Congress of the car in 1928 for suitable types of containers ${ }^{26}$.

Besides, the State Railways decided to participate in a society for the construction and the exercise of the containers.

\footnotetext{
${ }^{24}$ S. Maggi, Colonialism and communications: The railways in Italian Africa (Colonialismo e comunicazioni. Le strade ferrate nell'Africa Italiana), Esi, Naples, 1996, pp. 232-233.

${ }^{25} \mathrm{~F}$. Tajani, Competition and monopoly in transport, pp. 40-41.

${ }^{26}$ Ministero delle Comunicazioni: Amministrazione delle Ferrovie dello Stato, Report for the financial year 1930-31, p. 127.
} 


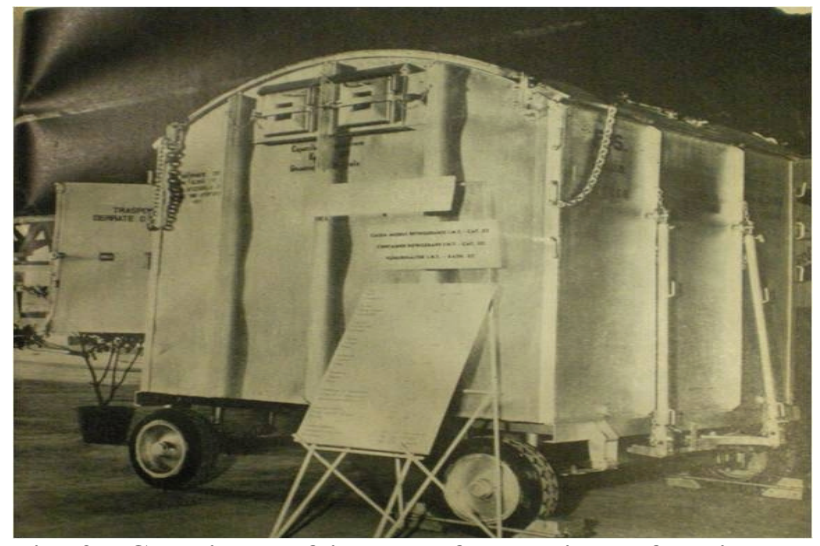

Fig. 2 Container refrigerants for carriage of perishable foodstuffs.

Source : G. Gazzetti, Il treno in casa, Quaderni delle Ferrovie Italiane dello Stato, n. 8, edizione 1957, p. 73.

The Sicon (Italian Society for Containers) was set well soon in liquidation, but the State Railways continued the construction of a certain number of mobile boxes and equip materials for the activation of a regular service on certain lines of traffic. The railway administration also participated in the works of the Bureau International des Containers for the resolution of technical problems, tariff and customs relating to international cargo of goods in the containers. In Italy, the dispositions for the transport of commodities with containers were established with ministerial decree published on the Official Gazette of January $25,1933^{27}$.

Two separate types of containers were set: a heavy type with a maximum weight of $5 \mathrm{t}$ and a light with a maximum weight of $2.5 \mathrm{t}$.

For the service of taking and delivery ${ }^{28}, 322$ containers of various types were used for experiment in 1936-1937, entrusted the management of the National Institute of Transport. Such boxes in 1938-1939 had become $2.522^{29}$.

However, there was not a strong tendency to make use of the container. It was noticed, a greater demand

\footnotetext{
${ }^{27} \mathrm{G}$. Gazzetti, The train at home, pp. 38-39.

${ }^{28}$ Ministero delle Comunicazioni. Amministrazione delle Ferrovie dello Stato, Report for the financial year 1936-37 (Relazione per l'anno finanziario 1936-37), Rome, 1938, p. 94.

${ }^{29}$ Ministero delle Comunicazioni. Amministrazione delle Ferrovie dello Stato, Report for the financial year 1938-39 (Relazione per l'anno finanziario 1938-39), Rome, 1940, p. 107.
}

for road trailers built to transport freight wagons, facilitating transport services from door to door.

During the Second World War, the conditions changed and transport had to adapt to the necessities of war, recovering also the traditional modality that used the rivers and had been abandoned.

The report on the management of the 1941 State Railways has been affirmed.

Always to the purpose to reserve the greatest possible quantity of rolling stock to the war necessities, the attention of the administration has been directed in order to make flow into the waterways, in the Veneto region and neighboring areas of bulk goods normally transported by rail. To such necessity a service of transports has been founded from Veneto to the Lombardy by mixed river and truck. Transport by boat were limited to Ostiglia, where the goods are transferred to trucks for forwarding to the places of destination ${ }^{30}$.

\section{Conclusions}

The attempt to coordinate transport in an overview, pursued by the Fascist regime, obtained a good success during the 1930s, when laws and institutions were created for this purpose.

Despite the propaganda autarky pursued in this period, Italy was included in the themes of the other European countries which looked at as role models to follow and imitate in the transport sector. There were, therefore, some achievements in other European countries, from which stemmed the national choices.

In 1935, the road freight traffic was regulated, providing that companies should be authorized by the Ministry of Communications through the General Inspectorate of the railways, trams and cars, on the basis of the eligibility requirements.

The road freight traffic was taxed to avoid trucking rates were too low compared to those of the trains,

\footnotetext{
${ }^{30}$ Ministero delle Comunicazioni: Amministrazione delle Ferrovie dello Stato, Report for the financial year 1940-1941 (Relazione per l'anno finanziario 1940-1941), Rome, 1941, p. 182.
} 
with the exception of connections between stations and places not served by trains.

Since 1929, the INT, a subsidiary of Ferrovie dello Stato, tried to overcome one of the advantages that the car had compared to rail: the service from door to door.

The desire to promote intermodal transport, both in goods and in the passenger sector, was abandoned after the Second World War, when attempts to coordinate transportation nationwide were overcome by the enormous spread of road transport. The debate on intermodality was resumed with the European Common Market in 1957, but it was international intermodality, no longer at the national level.

In the post-war Italy, the huge growth of trucks and cars led politicians to choose road transport as the future of mobility, making a strategic mistake that still Italy pays with pollution and traffic congestion.

\section{Bibliography}

[1] P. Biraghi, Defense of the Railway and Tramway Traffic, Tip. Ed. Minervini, Rome, 1931. (In Italian)

[2] B. Bolis, Roads for Trucks and Railways, Società Italiana per il Progresso delle Scienze, Rome, 1936. (In Italian)

[3] Q. Capaccioli, Discussion on Competition between Rail and Car, Stab. Grafico Commerciale, Florence, 1933. (In Italian)
[4] Combined Transport: 50 years of Experience, sous la direction de Michel Rachline, Compagnie nouvelle de conteneurs-transports nationaux et internationaux, Ed. Atlas, 1997. (In French)

[5] F. Corini, Economic Comparison between the Various Means of Transport, Officina Grafica Fresching, Parma, 1934. (In Italian)

[6] Gazzetti, The Train at Home, Vol. 8, Quaderni delle Ferrovie Italiane dello Stato, 1957. (In Italian)

[7] Istituto nazionale trasporti, In Twenty-Five of the INT, Rome, 1955. (In Italian)

[8] S. Maggi, Colonialism and communications. The railways in Italian Africa, Esi, Naples, 1996. (In Italian)

[9] M. Merger, M.N. Polino, COST 340: Towards a European Intermodal Transport Network: Lessons from History: A Critical Bibliography, Association pour l'Histoire des Chemins de Fer en France, Paris, 2004.

[10] V. Mezzatesta, Transport in the Economic Life of the Nation and the Issue of Motor Vehicles, Rivista Concessioni e Costruzioni, Rome, 1935. (In Italian)

[11] A. Pagello, On a Form of Coordination of Transport, Tip. G. Rumor, Vicenza, 1939. (In Italian)

[12] A. Pavone, Motor Vehicle and Rail, Tip. delle Terme, Rome, 1935. (In Italian)

[13] F. Tajani, Competition and Monopoly in Transport, The Fight between Rail and Car, Libreria Editrice Politecnica, Milan, 1936. (In Italian)

[14] R. Trevisani, The Competition between Road and Rail Transport in Economic Policy, Hoepli, Milan, 1937. (In Italian)

[15] F. Vezzani, Land Transport, Casa Editrice Poligrafica Universitaria, Florence, 1937. (In Italian) 